\title{
EVALUATION OF NUTRIENT STOCKS AND SOME SOIL INDICES OF AGRO-ECOSYSTEM AS AFFECTED BY LONG-TERM MONOCROPPING SYSTEM
}

\author{
AKINJIDE MOSES AFOLABI ${ }^{1}$, JOSEPH IKECHUKWU MUOGHALU ${ }^{1}$, EZEKIEL DARE OLOWOLAJU ${ }^{1}$, \\ FATIMOH OZAVIZE ADEMOH ${ }^{2 *}$
}

${ }^{1}$ Department of Botany, Obafemi Awolowo University, Ile-Ife, Nigeria. ${ }^{2}$ Department of Biological Science, Kogi State University, Ayingba. Email: jidetoluwa200@yahoo.com

Received: 05 May 2021, Revised and Accepted: 07 May 2021

ABSTRACT

Objectives: This study investigates nutrients stock and some soil indices of agro-ecosystem soil as affected by monoculture cropping system (cacao plantation). This was with a view to provide comprehensive understanding of soil nutrient dynamics in the ecosystems due to their different management practices.

Methods: The study was carried out in 0.063 ha sample plots, three each in natural forests and cacao plantations adjacent to each other. In each plot, five core soil samples were randomly collected at two depths (0-15 and 15-30 cm), bulked according to depth, air-dried, sieved through 2 mm sieve, and analyzed for soil physicochemical properties using standard methods. One-way analysis of variance was used to test significant mean differences of the soil properties among cacao plantation and natural forest at probability level $(\mathrm{p} \leq 0.05)$ at different soil depth.

Results: The results showed that soil physical properties such as particle size distribution, moisture contents, and bulk density; chemical properties such as pH, exchangeable cation, organic carbon, organic matter, phosphorus, and sulfur from natural forest were higher than the soil properties in cacao plantation for both top and subsoil. Soil indices such as soil structural stability index, base saturation percentage, and sodium adsorption ratio were higher in natural forest ecosystem than the soil indices of cacao plantation.

Conclusion: From this study, it can be concluded that long-term monoculture cropping system had significant effect on nutrients stock and soil indices. This subsequently might result in permanent soil degradation and productivity.

Keywords: Cacao, Land use, Plantations, Topsoil, Subsoil.

(C) 2021 The Authors. Published by Innovare Academic Sciences Pvt Ltd. This is an open access article under the CC BY license (http://creativecommons org/licenses/by/4.0/) DOI: http://dx.doi.org/10.22159/ijags.2021v9i3.40971. Journal homepage: https://innovareacademics.in/journals/index.php/ijags

\section{INTRODUCTION}

Monoculture cropping system is an agro-ecosystem commonly practice and developed in the southwestern region of Nigeria in which trees and shrubs are established and occurs from year to year. Longterm cropping often results in differences in physical, chemical, and biological properties of soil which, in turn, might lead to changes in the functional quality of soil $[1,2]$. Inappropriate long-term land use and cultivation pattern may result in the depletion of soil organic matter, organic carbon (OC), and subsequently to soil erosion, which might result in permanent soil gradation and productivity decreases $[3,4]$. Consequently, long-term cropping might also improve soil quality with good management systems $[4,5]$.

Many researchers [3,6-8] have also reported that long-term cropping system can play an important role in improving organic matter stock and maintaining soil nutrients such as total nitrogen (TN) stock which are important for both plants and microorganisms. According to Negasa et al. [9], the increase in yields in the past half-century is due to the intensification of soil long-term cultivation practices. From existing literatures, there is, therefore, a need to understand the impacts of long-term cropping system on soil quality to take appropriate measures that can enhance sustainable crop production. Hence, the hereby study investigates variations in nutrients stock and some soil indices of agro-ecosystem soil as affected by long-term monoculture cultivation practices.

\section{METHODS}

\section{Study area}

The study area is located at the agricultural farm of Ile-Oluji/Okeigbo local government area of Ondo State in Southwest Nigeria. It is situated approximately between latitude $5^{\circ} 15^{\prime}$ and $8^{\circ} 15^{\prime} \mathrm{N}$ and longitudes $4^{\circ}$ $31^{\prime}$ and $6^{\circ} 00^{\prime} \mathrm{E}$. This area lies within the rainforest vegetation zone of Nigeria. In the study catchment, mean annual temperature ranges between $21^{\circ} \mathrm{C}$ and $29^{\circ} \mathrm{C}$ and rainfall of $2000 \mathrm{~mm}$ was reported using Ondo State Ministry of Environment (2017) meteorological data. During the rainy season, however, the relative humidity of the air is high of about $87 \%$ and may be as low as $67 \%$. Monoculture cropping system is commonly practiced and is the dominant farming system for farmers' livelihoods. Cacao plantations are dominated over other land use types in the study catchment. This study catchment was selected as it represents agro-ecosystem conditions having a monocropping land use systems with practices such as diversified soil management practices and non-irrigated fields.

\section{Identification of long-term cropping land use systems}

Formal and informal discussions with farmers in the catchment area were used to identify the long-term cropping and their specific soil management practices. On the basis of the farmers' views in the discussion final consensus, long-term cacao dominant cropping was identified and described all their corresponding management practices. Continuous cacao crop (monocropped) has been grown for more than 20 years. 
Soil sampling procedure and analysis

Three sample plots, $25 \mathrm{~m} \times 25 \mathrm{~m}$ each, were established in three different natural forests and three different cacao plantations in the study area. Soil samples were collected in May 2015 in the sampling units at two depths of $0-15 \mathrm{~cm}$ and $15-30 \mathrm{~cm}$ using soil auger and replicated 5 times. The sampling depth was selected as occurred due to long-term cropping systems, land use types. Considering statistical representativeness and costs of soil analysis, a total of 27 composite soil samples from the sample plots were collected.

The analysis of the soil samples was carried out following the standard laboratory procedures of AACS. Soil texture was determined using the Bouyoucos hydrometer method [10] and soil dry bulk density by the core method [11]. Soil pH was determined using $\mathrm{pH}$ meter combined glass electrode [12], electrical conductivity (EC) using conductivity meter [13], soil OC by the Walkley-Black method [14], available phosphorus by Olsen method [15], and TN by Kjeldahl digestion method followed by distillation and titration [16].

Mineral elements $\left(\mathrm{Ca}^{2+}, \mathrm{Mg}^{2+}, \mathrm{K}^{+}\right.$, and $\left.\mathrm{Na}^{+}\right)$were analyzed after extracted in a 1:10 soil/solution ratio using $1 \mathrm{M}$ ammonium acetate at $\mathrm{pH}$ 7.0. $\mathrm{Ca}^{2+}$ and $\mathrm{Mg}^{2+}$ in the extracts were analyzed using atomic absorption spectrophotometer, whereas $\mathrm{Na}^{+}$and $\mathrm{K}^{+}$were determined by flame photometry [17]

\section{Soil indices}

Soil structural stability index (SSSI)

SSSI of the cacao plantation and natural forest was estimated using the formula stated by Pieri [18] and Serme et al. [19] as follows;

$$
\text { SSSI }=\frac{1.724 \times \% \text { OC }}{\% \text { Clay }+\_\% \text { Silt }} \times 100
$$

\section{Base saturation percentage (BSP)}

This was determined by the formula stated by Seilsepou and Rashidi [20] as follows;

$$
\mathrm{BSP}=\frac{\mathrm{Ca}^{2+}+\mathrm{Mg}^{2+}+\mathrm{Na}^{+}}{\mathrm{CEC}} \times 100 \%
$$

Sodium adsorption ratio (SAR)

SAR was determined using the formula stated by Elbashier et al. [21] as follows;

$$
\mathrm{SAR}=\mathrm{Na}^{+} / \sqrt{\mathrm{Ca}^{2+}+\mathrm{Mg}^{2+} / 2}
$$

Statistical analysis

Data were analyzed using statistical analytical software package (SAS) version 9.2. One-way analysis of variance was used to test significant mean differences of the soil properties among cacao plantation and natural forest at probability level $(\mathrm{p} \leq 0.05)$ at different soil depth. Mean values were separated using Duncan multiple range test.

\section{RESULTS AND DISCUSSION}

Physical properties of the topsoil $(0-15 \mathrm{~cm})$ as affected by longterm monoculture cropping system

There was variability in the soil physical properties at fixed depth of $0-15 \mathrm{~cm}$ (topsoil) of the agro ecosystems. Percentage clay, silt, and bulk density of the natural forest were higher than cacao plantation. Percentage sand of natural forest was lower than cacao plantation (Table 1). The variability in the soil physical properties may be attributed to continuous process of clearing, disposing, burning, and leveling of farming fields. These processes, in turn, promote weathering of native rocks, thereby leading to lower SSSI of the topsoil in the cacao (long-term plantation) compared to natural forest.

Mineral nutrients of the topsoil $(0-15 \mathrm{~cm})$ as affected by long-term monoculture cropping system

$\mathrm{The}^{2+}, \mathrm{Mg}^{2+}, \mathrm{K}^{+}, \mathrm{Na}^{+}$, and $\mathrm{Mn}^{2+}$ contents in the topsoil of the agroecosystems were highest in natural forest and lowest in the cacao plantation. There was a significant difference in the $\mathrm{Ca}^{2+}, \mathrm{Mg}^{2+}, \mathrm{K}^{+}$, and $\mathrm{Na}^{+}$contents of the topsoil among agro-ecosystems (Table 2). Longterm land use and poor agronomic practices have been reported to deplete soil $\mathrm{Ca}^{2+}, \mathrm{Mg}^{2+}, \mathrm{K}^{+}, \mathrm{Na}^{+}$, and $\mathrm{Mn}^{2+}$ contents, thereby lowering soil productivity. These, therefore, accounted for lower $\mathrm{Ca}^{2+}, \mathrm{Mg}^{2+}, \mathrm{K}^{+}, \mathrm{Na}^{+}$, and $\mathrm{Mn}^{2+}$ in cacao plantation than in the natural forest.

Soil nutrients of the topsoil $(0-15 \mathrm{~cm})$ as affected by long-term monoculture cropping system

The soil $\mathrm{pH}$ varied significantly among the agro-ecosystems from 6.93 to 7.03 with the highest in natural forest and lowest in the cacao plantation. The highest percentage of $\mathrm{OC}$ and matter was found to be highest in natural forest and lowest in the cacao plantation (Table 3). Available phosphorus, moisture content, and TN were highest in natural forest and lowest in the cacao plantation. Furthermore, EC of the topsoil was highest in natural forest and lowest in the cacao plantation (Table 3). This happened because of intensive farming over a long period of years. This result is in line with the study of $[22,23]$ who stated that land use changes alter percentage soil of OC and matter, available phosphorus, moisture content, and TN [24]. Furthermore, land use management has been among anthropogenic factors contributing depletion of OC and matter, available phosphorus, moisture content, and TN [25].

Soil indices of the topsoil $(0-15 \mathrm{~cm})$ as affected by long-term monoculture cropping system

SSSI, SAR SSSI, and BSP were significantly varied among the agroecosystems. The highest SSSI and SAR were recorded from natural forest and the lowest from cacao plantation, while BSP of cacao plantation was higher than natural forest (Table 4). This could be attributed to the effects of long-term land usage leading to the depression and depletion of soil nutrients, thereby influencing SSSI and SAR.

Physical properties of the subsoil (15-30 cm) as affected by longterm monoculture cropping system

The lowest sand contents and bulk density were observed from cacao plantation whereas the highest were observed from the natural forest The highest clay contents were observed in the cacao plantation and lowest in the natural forest. Both the cacao plantation and forest agro-ecosystems had the same percentage silt contents (Table 5). The percentage physical properties among agro-ecosystems were significant except for the percentage silt content which there was no significant differences among the agro-ecosystems. The highest clay content and lowest sand in cacao plantation may be attributed to

Table 1: Physical properties of the topsoil $(0-15 \mathrm{~cm})$ as affected by long-term monoculture cropping system

\begin{tabular}{lll}
\hline Physical properties & $\begin{array}{l}\text { Cacao (long-term } \\
\text { plantation) }\end{array}$ & $\begin{array}{l}\text { Natural } \\
\text { forest }\end{array}$ \\
\hline Clay\% & $7.00^{\mathrm{b}}$ & $8.67^{\mathrm{a}}$ \\
Sand\% & $74.33^{\mathrm{a}}$ & $72.00^{\mathrm{b}}$ \\
Silt\% & $18.67^{\mathrm{b}}$ & $19.33^{\mathrm{a}}$ \\
Bulk density & $0.95^{\mathrm{b}}$ & $1.04^{\mathrm{a}}$ \\
\hline
\end{tabular}

Means with the same letter long the same rows are not significantly different at $P \leq 0.05$

Table 2: Mineral elements of the topsoil $(0-15 \mathrm{~cm})$ as affected by long-term monoculture cropping system

\begin{tabular}{lll}
\hline Exchangeable bases & Cacao (long-term plantation) & Natural forest \\
\hline $\mathrm{Ca}^{2+}$ & $6.82^{\mathrm{b}}$ & $7.71^{\mathrm{a}}$ \\
$\mathrm{Mg}^{2+}$ & $0.95^{\mathrm{b}}$ & $1.09^{\mathrm{a}}$ \\
$\mathrm{K}^{+}$ & $0.84^{\mathrm{b}}$ & $0.96^{\mathrm{a}}$ \\
$\mathrm{Na}^{+}$ & $0.15^{\mathrm{b}}$ & $0.17^{\mathrm{a}}$ \\
$\mathrm{Mn}^{2+}$ & $0.01^{\mathrm{b}}$ & $0.02^{\mathrm{a}}$
\end{tabular}

Means with the same letter long the same rows are not significantly different at $P \leq 0.05$ 
Table 3: Soil nutrients of the topsoil $(0-15 \mathrm{~cm})$ as affected by long-term monoculture cropping system

\begin{tabular}{lll}
\hline Soil nutrients & $\begin{array}{l}\text { Cacao (long-term } \\
\text { plantation) }\end{array}$ & $\begin{array}{l}\text { Natural } \\
\text { forest }\end{array}$ \\
\hline Soil pH & $6.93^{\mathrm{b}}$ & $7.03^{\mathrm{a}}$ \\
Organic carbon (\%) & $2.71^{\mathrm{b}}$ & $2.74^{\mathrm{a}}$ \\
Organic matter & $4.43^{\mathrm{b}}$ & $5.05^{\mathrm{a}}$ \\
Electrical conductivity $\left(\mathrm{ds} \mathrm{m}^{-1}\right)$ & $0.02^{\mathrm{b}}$ & $0.03^{\mathrm{a}}$ \\
Available phosphorus & $0.04^{\mathrm{b}}$ & $0.05^{\mathrm{a}}$ \\
Moisture content & $7.78^{\mathrm{b}}$ & $8.94^{\mathrm{a}}$ \\
Total nitrogen & $0.45^{\mathrm{b}}$ & $0.51^{\mathrm{a}}$ \\
\hline
\end{tabular}

Means with the same letter long the same row are not significantly different at $P \leq 0.05$

Table 4: Soil indices of the topsoil $(0-15 \mathrm{~cm})$ as affected by long-term monoculture cropping system

\begin{tabular}{lll}
\hline Soil Indices & $\begin{array}{l}\text { Cacao (long-term } \\
\text { plantation) }\end{array}$ & $\begin{array}{l}\text { Natural } \\
\text { forest }\end{array}$ \\
\hline Soil structural stability index & $18.20^{\mathrm{b}}$ & $31.38^{\mathrm{a}}$ \\
Base saturation percentage & $43.80^{\mathrm{a}}$ & $33.10^{\mathrm{b}}$ \\
Sodium adsorption ratio & $0.10^{\mathrm{b}}$ & $0.11^{\mathrm{a}}$ \\
\hline
\end{tabular}

Means with the same letter long the same rows are not significantly different at $P \leq 0.05$

Table 5: Physical properties of the subsoil $(15-30 \mathrm{~cm})$ as affected by long-term monoculture cropping system

\begin{tabular}{lll}
\hline Physical properties & $\begin{array}{l}\text { Cacao (long-term } \\
\text { plantation) }\end{array}$ & $\begin{array}{l}\text { Natural } \\
\text { forest }\end{array}$ \\
\hline Clay\% & $27.00^{\mathrm{a}}$ & $23.00^{\mathrm{b}}$ \\
Sand\% & $62.00^{\mathrm{b}}$ & $66.0^{\mathrm{a}}$ \\
Silt $\%$ & $11.00^{\mathrm{a}}$ & $11.00^{\mathrm{a}}$ \\
Bulk density & $0.85^{\mathrm{b}}$ & $0.96^{\mathrm{a}}$ \\
\hline Means with the same letter long the same rows are not significantly different
\end{tabular}

Means with the same letter long the same rows are not significantly different at $P \leq 0.05$

repeated cultivation due to long-term organic fertilization usage in which such practices aggravate effect of erosion that erodes coarse soil particles and leaves fine soil particles. The variation in bulk density and SSSI among could be attributed to long duration of the cropping system and variability in management practices.

Mineral elements of the subsoil $(15-30 \mathrm{~cm})$ as affected by longterm monoculture cropping system

The soil $\mathrm{Ca}^{2}+, \mathrm{Mg}^{2+}, \mathrm{K}^{+}$, and $\mathrm{Na}^{+}$varied significantly between agroecosystems, with the highest values observed from natural forest and lowest from cacao plantation, respectively. $\mathrm{Mn}^{2+}$ content in both cacao plantation and natural forest was the same (Table 6). The significant lower content of $\mathrm{Ca}^{2}+, \mathrm{Mg}^{2+}, \mathrm{K}^{+}$, and $\mathrm{Na}^{+}$may be as a result of long-term cropping, type of vegetation, and cover with limited litter addition on soil surface, resulting into little addition of soil $\mathrm{Ca}^{2}+, \mathrm{Mg}^{2+}, \mathrm{K}^{+}$, and $\mathrm{Na}^{+}$, exchangeable bases of the subsoil $(15-30 \mathrm{~cm})$ as affected by long-term monoculture cropping system

Soil nutrients of the subsoil $(15-30 \mathrm{~cm})$ as affected by long-term monoculture cropping system

The soil pH varied significantly among agro-ecosystems from 5.47 to 5.70 with the highest in cacao plantation and lowest in natural forest. OC, available phosphorus, moisture content, and TN of natural forest were higher than that of cacao plantation. Organic matter was highest in cacao plantation and lowest in the natural forest. Both the cacao plantation and natural forest had the same EC. There were statistically significant differences in soil chemical properties among agroecosystems (Table 7). The higher $\mathrm{pH}$ in cacao plantation could be as a
Table 6: Mineral elements of the subsoil $(15-30 \mathrm{~cm})$ as affected by long-term monoculture cropping system

\begin{tabular}{lll}
\hline $\begin{array}{l}\text { Exchangeable } \\
\text { bases }\end{array}$ & $\begin{array}{l}\text { Cacao (long-term } \\
\text { plantation) }\end{array}$ & $\begin{array}{l}\text { Natural } \\
\text { forest }\end{array}$ \\
\hline $\mathrm{Ca}^{2+}$ & $4.39^{\mathrm{b}}$ & $4.88^{\mathrm{a}}$ \\
$\mathrm{Mg}^{2+}$ & $0.61^{\mathrm{b}}$ & $0.68^{\mathrm{a}}$ \\
$\mathrm{K}^{+}$ & $0.54^{\mathrm{b}}$ & $0.60^{\mathrm{a}}$ \\
$\mathrm{Na}^{+}$ & $0.09^{\mathrm{b}}$ & $0.11^{\mathrm{a}}$ \\
$\mathrm{Mn}^{2+}$ & $0.01^{\mathrm{a}}$ & $0.01^{\mathrm{a}}$ \\
\hline
\end{tabular}

Means with the same letter long the same rows are not significantly different at $P \leq 0.05$

Table 7: Soil nutrients of the subsoil $(15-30 \mathrm{~cm})$ as affected by long-term monoculture cropping system

\begin{tabular}{lll}
\hline Soil nutrients & $\begin{array}{l}\text { Cacao (long-term } \\
\text { plantation) }\end{array}$ & $\begin{array}{l}\text { Natural } \\
\text { forest }\end{array}$ \\
\hline Soil pH & $5.70^{\mathrm{a}}$ & $5.47^{\mathrm{b}}$ \\
Organic carbon (\%) & $1.98^{\mathrm{b}}$ & $2.20^{\mathrm{a}}$ \\
Organic matter & $3.40^{\mathrm{a}}$ & $3.37^{\mathrm{b}}$ \\
Electrical conductivity $\left(\mathrm{ds} \mathrm{m}^{-1}\right)$ & $0.02^{\mathrm{a}}$ & $0.02^{\mathrm{a}}$ \\
Available phosphorus & $0.026^{\mathrm{b}}$ & $0.029^{\mathrm{a}}$ \\
Moisture content & $8.82^{\mathrm{b}}$ & $10.19^{\mathrm{a}}$ \\
Total nitrogen\% & $0.29^{\mathrm{b}}$ & $0.32^{\mathrm{a}}$ \\
\hline
\end{tabular}

Means with the same letter long the same rows are not significantly different at $P \leq 0.05$

Table 8: Soil indices of the subsoil $(15-30 \mathrm{~cm})$ as affected by long-term monoculture cropping system

\begin{tabular}{lll}
\hline Soil indices & $\begin{array}{l}\text { Cacao (long-term } \\
\text { plantation) }\end{array}$ & $\begin{array}{l}\text { Natural } \\
\text { forest }\end{array}$ \\
\hline Soil structural stability index & $11.25^{\mathrm{a}}$ & $11.16^{\mathrm{b}}$ \\
Base saturation percentage & $28.15^{\mathrm{a}}$ & $20.90^{\mathrm{b}}$ \\
Sodium adsorption ratio & $0.08^{\mathrm{b}}$ & $0.09^{\mathrm{a}}$ \\
\hline Means with the same letter long the same rows are not significantly different at \\
$P \leq 0.05$
\end{tabular}

result of low leaching of basic cations from topsoil to subsoil exchange complex. Lower OC, available phosphorus, moisture content, and TN of cacao plantation compared to the natural forest occur due to changes in the rates of accumulation of nutrients by the dominated crop, nutrients turnover, and decomposition in the cacao plantation $[25,26]$.

Soil indices of the subsoil $(15-30 \mathrm{~cm})$ as affected by long-term monoculture cropping system

The highest SSSI and BSP of the subsoil $(15-30 \mathrm{~cm})$ were recorded from cacao plantation and the lowest from natural forest, whereas the lowest SAR was recorded in cacao plantation. However, there were significant differences in SSSI, BSP, and SAR among agro-). The observed higher SSSI and BSP of cacao plantation of the subsoil $(15-30 \mathrm{~cm})$ could be attributed to the differences in soil nutrients and exchangeable bases both at the top (0-15) and subsoil $(15-30 \mathrm{~cm})$ (Table 8).

\section{CONCLUSION}

This study revealed that soil properties, nutrient stocks, and soil indices were significantly varied across the agro-ecosystem. These variations found to be attributed mainly to the difference in nutrients turnover, duration of the cropping system, and variability in management practices.

Therefore, long-term monoculture cropping system had significant influence on nutrient stocks and soil indices by depleting mineral nutrients, soil organic matter, OC, moisture content, available phosphorus, TN, SSSI, BSP, and SAR at the topsoil and subsoil. This subsequently might result in permanent soil degradation and productivity. 


\section{CONFLICTS OF INTEREST STATEMENT}

Authors declare no conflicts of interest.

\section{REFERENCES}

1. Arshad MA, Martin S. Identifying critical limits for soil quality indicators in agro-ecosystems. Agric Ecosyst Environ 2002;88:153-60.

2. Yildirim E, Guvenc I Intercropping based on cauliflower: More productive, profitable and highly sustainable. Eur J Agron 2005;22: 11-8.

3. Sharma KL, Mandal B, Venkateswarlu B. Soil quality and productivity improvement under rainfed conditions- Indian perspectives. In: Abrol V, Sharma P, editors. Resource Management for Sustainable Agriculture. London: InTech Open; 2012.

4. Zhao Q, Liu S, Deng L, Dong S, Wang C. Soil degradation associated with water-level fluctuations in the Manwan Reservoir, Lancang River Basin. Catena 2014;113:226-35.

5. Hurni H, Tato K, Zeleke G. The implications of changes in population, land use, and land management for surface runoff in the upper Nile basin area of Ethiopia. Mt Res Dev 2005;25:147-54.

6. Lal R. Soil carbon sequestration to mitigate climate change. Geoderma 2004;123:1-22.

7. Mandal B, Majumder B, Bandyopadhyay PK. The potential of cropping systems and soil amendments for carbon sequestration in soils under long-term experiments in subtropical India. Glob Change Biol 2007;13:357-69.

8. Yesilonis I, Szlavecz K, Pouyat R, Whigham D, Xia L. Historical land use and stand age effects on forest soil properties in the Mid-Atlantic US. For Ecol Manag 2016;370:83-92.

9. Negasa T, Ketema H, Legesse A, Sisay M, Temesgen H. Variation in soil properties under different land use types managed by smallholder farmers along the toposequence in Southern Ethiopia. Geoderma 2017;290:40-50.

10. Gee GW, Bauder JW. Particle-size analysis. In: Klute A, editor. Part 1: Methods of Soil Analysis. $2^{\text {nd }}$ ed. Madison, WI: American Society of Agronomy, Soil Science Society of America Book; 1986.

11. Blake GR, Hartge KH. Bulk density. In: Klute A, editor. Part 1: Methods of Soil Analysis. $2^{\text {nd }}$ ed. Madison, WI: American Society of Agronomy, Soil Science Society of America Book; 1986.

12. Thomas GW. Soil pH and soil acidity. In: Sparks DL, editor. Part 3 Methods of Soil Analysis. Chemical Methods. Madison, WI: Soil Science Society of America; 1996. p. 475-90.

13. Rhoades JD. Soluble salts. In: Page AL, editor. Methods of Soil
Analysis. Vol. 2. Madison, WI: American Society of Agronomy, Soil Science Society of America Book; 1982. p. 167-79.

14. Bremmer J, Mulvaney CS. Nitrogen total. In: Page AL, editor. Method of Soil Analysis. Part 2: Chemical and Microbiological Properties. Agronomy Monographs 9. Madison, WI: American Society of Agronomy; 1982

15. Olsen SR, Sommers LE. Phosphorus. In: Page AL, editor. Method of Soil Analysis. Part 2: Chemical and Microbiological Properties. Agronomy Monograph 9. Madison, WI: American Society of Agronomy; 1982.

16. Anderson JM, Ingram JS. Tropical Soil Biology and Fertility: A Handbook of Methods. Wallingford: CAB International; 1993.

17. Black CA, Evans DD, White JL, Ensminger LE, Clark FE. Methods of Soil Analysis. Part 1: Physical and Mineralogical Properties, Including Statistics of Measurement and Sampling. Madison, WI: American Society of Agronomy; 1965

18. Pieri CJ. Fertility of Soils: A Future for Farming in the West African Savannah. Berlin: Springer-Verlag; 1992.

19. Serme I, Ouattara K, Ouattara B, Taonda SJB. Short term impact of tillage and fertility management on Lixisol structural degradation. Int J Agric Policy Res 2016;4:1-6.

20. Seilsepou M, Rashidi M. Modeling of soil sodium adsorption ratio based on soil electrical conductivity. ARPN J Agric Biol Sci 2008;3:27-31.

21. Elbashier MM, Ebrahim MH, Musa AA, Ali AA, Mohammed MA. Efficiency of two models for prediction of exchangeable sodium percentage from sodium adsorption ratio on saline and non saline soil. Univ J Agric Res 2016;4:32-6.

22. Corsi S, Friedrich T, Kassam A, Pisante M. Sà JM. Soil Organic Carbon Accumulation and Greenhouse Gas Emission Reductions from Conservation Agriculture: A Literature Review. Integrated Crop Management. Rome, Italy: Plant Production and Protection Division Food and Agriculture Organization; 2012.

23. Singh B, Ryan J. Managing Fertilizers on Enhance Soil Health. $1^{\text {st }}$ ed. Paris, France: IFA; 2015. p. 23.

24. Atkins JW, Estein HE, Welsch DL. Vegetation and elevation influence the timing and magnitude of soil CO2 efflux in a humid, topographically complex watershed. Biogeosciences 2015;12:2975-94.

25. Liu W, Xu W, Hong J, Wan S. Interannual variability of soil microbial biomass and respiration in responses to topography, annual burning and $\mathrm{N}$ addition in a semiarid temperate steppe. Geoderma 2010;158:259-67.

26. Poeplau C, Don A, Vesterdal L, Leifeld J, Van Wesemael B, Schumacher J, et al. Temporal dynamics of soil organic carbon after land-use change in the temperate zone - carbon response functions as a model approach. Glob Change Biol 2011;17:2415-27. 